DOI: https://doi.org/10.24127/ajpm.v9i4.3137

\title{
IMPLEMENTASI PEMBELAJARAN INTERAKTIF KALKULUS DENGAN WOLFRAM CDF PLAYER PADA KELAS SEMU SCHOOLOGY
}

\author{
Adi Nurcahyo $^{*}$, Naufal Ishartono ${ }^{2}$, Nugroho Arif Sudibyo ${ }^{3}$ \\ ${ }^{1 *, 2}$ Pendidikan Matematika, Universitas Muhammadiyah Surakarta, Surakarta, Indonesia \\ ${ }^{3}$ Teknik Informatika, Universitas Duta Bangsa, Surakarta, Indonesia \\ *Corresponding author. Tegalrejo RT 02 RW 01 Paulan Colomadu Karanganyar, 57177, Karanganyar, Indonesia \\ E-mail: $\quad$ adi.nurcahyo@ums.ac.id $^{\left.{ }^{*}\right)}$ \\ $\underline{\text { naufal.ishartono@ums.ac.id }}^{2)}$ \\ nugroho_arif@udb.ac.id ${ }^{3}$
}

Received 25 October 2020; Received in revised form 22 November 2020; Accepted 16 December 2020

\begin{abstract}
Abstrak
Penggunaan teknologi dengan menerapkan e-learning merupakan hal yang dibutuhkan dalam pembelajaran. Tujuan dari penelitian ini yaitu untuk melihat hasil dari implementasi pembelajaran kalkulus dengan Wolfram CDF ke dalam kelas semu Schoology. Metode perancangan sistem yang digunakan yaitu RAD (Rapid Application Development). Tahapan yang dilakukan meliputi 1) Requirement planning (perencanaan kebutuhan), 2) User design (desain pengguna), 3) Construction (pembangunan sistem), dan 4) Cut over (evaluasi). Teknik pengambilan data yang digunakan berupa observasi, wawancara, dan angket. Subjek penelitian ini yaitu mahasiswa semester satu Program Studi Pendidikan Matematika FKIP UMS tahun ajaran 2018/2019 sebanyak 120 mahasiswa. Hasil dari penelitian ini berupa suatu media pembelajaran interaktif kalkulus dengan kelas semu Schoology. Penerapan teknologi yang dilakukan dengan Wolfram CDF dan Schoology membantu dalam kegiatan pembelajaran. Sebanyak 87 mahasiswa menyatakan media pembelajaran tergolong sangat baik dan 33 mahasiswa menyatakan media pembelajaran tergolong baik. Dengan adanya pembelajaran kelas semu yang digunakan, mahasiswa juga mendapatkan beberapa manfaat lain dalam pembelajaran kelas online diantaranya pemahaman tentang kemampuan informasi dan teknologi.
\end{abstract}

Kata kunci: Kalkulus, pembelajaran interaktif, RAD, Wolfram.

\begin{abstract}
The use of technology by implementing e-learning is what is needed in learning. The purpose of this study is to see the results of the implementation of calculus learning with Wolfram CDF in the Schoology pseudo-class. The system design method used is RAD (Rapid Application Development). The stages carried out include 1) Requirement planning, 2) User design, 3) Construction and 4) Cutover. The data collection techniques used were observation, interviews, and questionnaires. The subjects of this research were 120 students in the first semester of the Mathematics Education Study Program FKIP UMS academic year 2018/2019. The results of this study were in the form of a calculus interactive learning media with Schoology pseudo-class. The application of technology with Wolfram CDF and Schoology helps in learning activities. A total of 87 students stated that the learning media was very good and 33 students stated that the learning media was good. With the pseudo classroom learning used, students also get several other benefits in online classroom learning including an understanding of information and technology skills.
\end{abstract}

Keywords: Calculus, interactive learning, RAD, Wolfram 
DOI: https://doi.org/10.24127/ajpm.v9i4.3137

\section{PENDAHULUAN}

Penggunaan teknologi dalam pendidikan memainkan peranan penting dalam peningkatan hasil belajar (Srisawasdi \& Panjaburee, 2014). Penerapan teknologi dalam pengajaran dan pembelajaran matematika dapat meningkatkan keterlibatan siswa (Attard \& Holmes, 2020) dan fokus siswa pada materi yang sulit (Khouyibaba, 2010). Salah satu bentuk penerapan teknologi dalam pembelajaran yaitu electronic learning (e-learning). Dalam praktik pembelajaran yang dilakukan, $e$ learning menggunakan teknologi informasi sebagai sarana belajar dalam pembelajaran. Penggunaan e-learning mendukung efisiensi pembelajaran dengan adanya pembelajaran berbasis komputer, pembelajaran berbasis web, dan kelas virtual (Areerachakul, 2015). Adanya penggunaan teknologi dengan menerapkan e-learning merupakan hal yang dibutuhkan dalam pembelajaran.

Salah satu bentuk matematika yang digunakan di perguruan tinggi yaitu kalkulus. Konsep turunan pada materi kalkulus dipelajari pada mata kuliah kalkulus diferensial. Fungsi, limit fungsi, derivatif, derivatif dari berbagai macam fungsi dan aplikasi derivatif merupakan materi mata kuliah kalkulus diferensial (HW, 2007). Kalkulus diferensial menjadi mata kuliah prasayarat untuk mengambil mata kuliah kalkulus integral, kalkulus peubah banyak, dan persamaan diferensial.

Berdasarkan data hasil UTS mata kuliah kalkulus diferensial tahun ajaran 2019/2020 dari 34 mahasiswa didapat rata-rata 44.029. Hal ini menandakan terdapat kelemahan pada pemahaman mahasiswa terhadap materi kalkulus diferensial. Beberapa kelemahan pada pemahaman mahasiswa terhadap teorema dasar kalkulus terdapat dalam konsep turunan (Monariska, 2019; Suprihatiningsih et al., 2020). Faktorfaktor yang mempengaruhi kesulitan mahasiswa dalam materi kalkulus diantaranya kurang cermat dalam melakukan perhitungan, dan kemampuan mengelola waktu dalam mengerjakan (Rejeki \& Setyaningsih, 2016). Oleh karena itu, soal yang dikerjakan belum dapat dikerjakan dengan baik. Hal yang mempunyai pengaruh terhadap pencapaian belajar yaitu partisipasi siswa dalam proses pembelajaran (Gunawan, 2017; Saputra \& Andriyani, 2019).

Pengajar memberikan peranan yang penting terhadap keefektifan dan efisiensi penggunaan teknologi dalam pembelajaran (Ghimire et al., 2019). Tetapi kebanyakan pengajar belum menerapkan teknologi dalam pembelajaran (e-learning) dikarenakan penggunaannya yang dianggap menyulitkan. Belum diterapkannya $e$ learning karena guru merasa kesulitan menggunakan e-learning dalam hal terbatasnya waktu, masalah keuangan, terbatasnya waktu berlatih, dan permasalahan internet (Brahim et al., 2014). Untuk memudahkan guru dalam menyampaikan pembelajaran dengan $e$ learning bisa memanfaatkan platform Learning Management System (LMS). Penggunaan LMS dapat memberikan gambaran sistem yang bervariasi dalam pembelajaran online terhadap siswa, guru, dan pengelola atau sekolah (Aldiab et al., 2019).

Salah satu bentuk aplikasi pengembangan kelas digital dengan menggunakan LMS yaitu Schoology (Afriyanti et al., 2018). Penggunaan Schoology dalam pembelajaran layak untuk digunakan dengan koneksi internet yang baik dan umpan balik 
yang diperbaiki (Warsito \& Djuniadi, 2016).

Beberapa penelitian sebelumnya menyimpulkan bahwa Schoology efektif digunakan dalam pembelajaran daring (Firmansyah, 2015), Selain itu juga Schoology dapat meningkatkan keterampilan berpikir kritis (Ardianti et al., 2019). Kemudahan dalam Schoology yang meliputi cara pemakaian, tampilan, dan pengerjaan kuis dapat memotivasi dalam belajar (Rosalina, 2018). Adanya aplikasi Schoology teruji efektif dalam menghasilkan ketuntasan belajar (Wahyudi, 2017). Sehingga dapat disimpulkan bahwa Schoology efektif diterapkan dalam pembelajaran khususnya pembelajaran daring untuk meningkatkan pemahaman siswa.

Hasil penelitian penggunaan Schoology yang dilakukan sebagian besar masih dilakukan pada pendidikan tingkat menengah, masing sangat sedikit yang mengimplementasikan ada pendidikan tinggi. Sehingga perlu adanya upaya untuk menerapkannya pada perguruan tinggi.

Pada tahun 2018, penelitian yang dilakukan oleh (Hidayat \& Sudibyo, 2018) menyatakan bahwa pembelajaran interaktif dapat diterapkan pada Google Classroom dengan menggunakan Adobe Flash. Selanjutnya, penelitian yang dilakukan oleh (Rifa'i, 2019) pembelajaran kalkulus menggunakan media pembelajaran website Moodle dapat meningkatkan hasil pembelajaran. Oleh sebab itu, media pembelajaran interaktif penting digunakan dalam pembelajaran (Rahmat, 2015). Dengan adanya pembelajaran interaktif dapat merangsang kemauan belajar mandiri, partisipasi aktif mahasiswa dalam pembelajaran, serta kemampuan teknologi, informasi dan komunikasi
(O'dwyer et al., 2007; Parkes et al., 2011; Pratama \& Nur Ismiyati, 2019)

Berdasarkan uraian tersebut, akan dirancang suatu pembelajaran interaktif kalkulus dengan kelas semu Schoology pada pembelajaran Kalkulus Diferensial. Adanya penggunaan kelas semu Schoology bertujuan untuk mengetahui hasil implementasi Wolfram RAD terhadap pembelajaran kalkulus diferensial

\section{METODE PENELITIAN}

Metode perancangan sistem menggunakan metode RAD (Rapid Application Development) (Hidayat \& Sudibyo, 2018). Tahapan model RAD sebagai berikut: 1) Requirement planning (perencanaan kebutuhan). 2) User design (desain pengguna), 3) Construction (pembangunan sistem), dan 4) Cut over (evaluasi). Rancangan RAD ditampilkan pada Gambar 1.

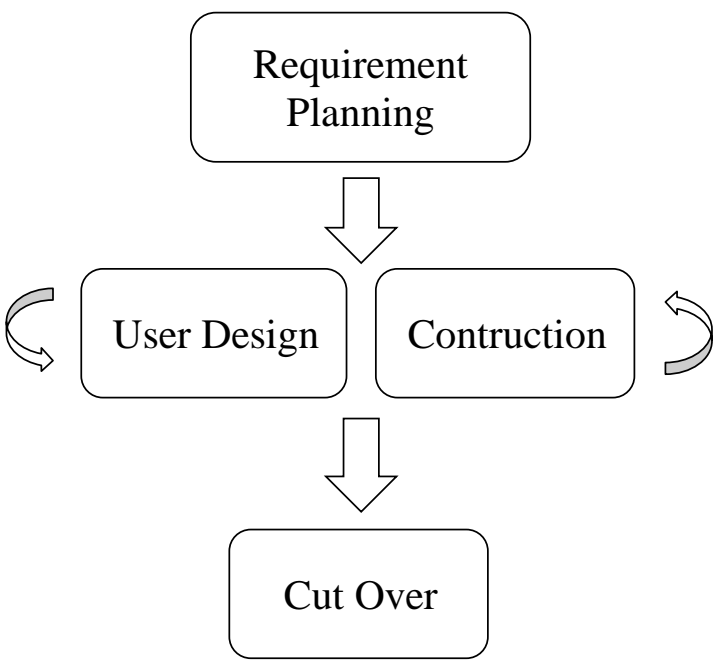

Gambar 1. Rancangan RAD

Pada tahapan requirement planning (perencanaan kebutuhan) dilakukan pengamatan secara langsung objek penelitian yaitu kelas Kalkulus Diferensial tahun 2019/2020. Kemudian dilakukan metode interview secara langsung pada mahasiswa kelas 
Kalkulus diferensial tahun 2019/2020. Setelah itu, akan dilakukan metode dokumentasi di kelas Kalkulus diferensial tahun 2019/2020 dan dilanjutkan dengan studi pustaka.

Tahapan User design (desain pengguna) merupakan perancangan user interface. Dalam user design, menu yang menampilkan menu materi dan evaluasi turunan. Tahap construction (pembangunan sistem), setiap menu tersebut akan diberikan link didalamnya terdapat materi dan evaluasi turunan. Tahap cut over (evaluasi) merupakan proses evaluasi sistem setelah digunakan dalam sistem belajar.

Subjek penelitian yaitu mahasiswa Pendidikan Matematika FKIP UMS tahun ajaran 2019/2020 yang mengambil mata kuliah kalkulus diferensial sebanyak 120 mahasiswa. Instrumen dan teknik pengumpulan data yang digunakan yaitu metode observasi, wawancara, dan angket. Teknik analisis data yang digunakan berupa teknik analisis kuantitatif dan kualitatif. Analisis kuantitatif dilakukan terhadap angket yang diberikan sedangkan analisis kualitatif digunakan untuk menganalisis wawancara dan dokumentasi.

Tahap selanjutnya dilakukan validasi dari ahli materi dan ahli media yang kemudian mahasiswa yang menempuh mata kuliah kalkulus diferensial melakukan pengujian akhir dengan penggunaan kelas semu Schoology menggunakan implementasi Wolfram CDF. Model analisis Miles dan Huberman digunakan dalam penelitian ini (Susandi \& Widyawati, 2017) untuk menentukan penilaian terhadap media yang dibuat. Penilaian yang diberikan menggunakan kategori pada Tabel 1.
Tabel 1. Kategori penilaian.

\begin{tabular}{cc}
\hline Interval & Kategori \\
\hline $\mathrm{X}>\mathrm{M}+1,5 \mathrm{SD}$ & Sangat Baik \\
$\mathrm{M}+0,5 \mathrm{SD}<\mathrm{X} \leq \mathrm{M}+1,5 \mathrm{SD}$ & Baik \\
$\mathrm{M}-0,5 \mathrm{SD}<\mathrm{X} \leq \mathrm{M}+0,5 \mathrm{SD}$ & Cukup \\
$\mathrm{M}-1,5 \mathrm{SD}<\mathrm{X} \leq \mathrm{M}-1,5 \mathrm{SD}$ & Kurang \\
$\mathrm{X} \leq \mathrm{M}-1,5 \mathrm{SD}$ & Sangat Kurang \\
\hline
\end{tabular}

\section{HASIL DAN PEMBAHASAN}

Tahapan dalam penggunaan kelas semu schoology yang dilakukan yaitu meliputi perencanaan kebutuhan (requirement planning). Dalam perencanaan kebutuhan dilakukan dengan studi pendahuluan riset. Studi Hasil yang diperoleh dari observasi yang telah dilakukan terhadap 10 mahasiswa, diperoleh hasil bahwa smartphone belum banyak digunakan untuk membantu belajar mandiri. Ada 8 mahasiswa yang senang dengan media visual, ada 7 mahasiswa yang belum paham dengan materi turunan. Dari hasil observasi yang dilakukan, maka kelas semu Schoology diterapkan dalam pembelajaran.

Halaman utama dari e-learning mata kuliah Kalkulus Diferensial menggunakan Schoology ditampilkan pada Gambar 2. Dalam Schoology terdapat beberapa fasilitas yang disediakan diantaranya add folder, add assigment, add assessment, add fle/link/external tool, add discussion, add page serta add media album. Keseluruhan fasilitas yang ada dapat digunakan untuk melengkapi kebutuhan dalam pembelajaran menggunakan schoology.

Untuk bergabung dengan kelas kalkulus diferensial menggunakan kode akses yang terdapat dalam kelas Schoology. tampilan kode akses Schoology ditampilkan Gambar 3. 
DOI: https://doi.org/10.24127/ajpm.v9i4.3137

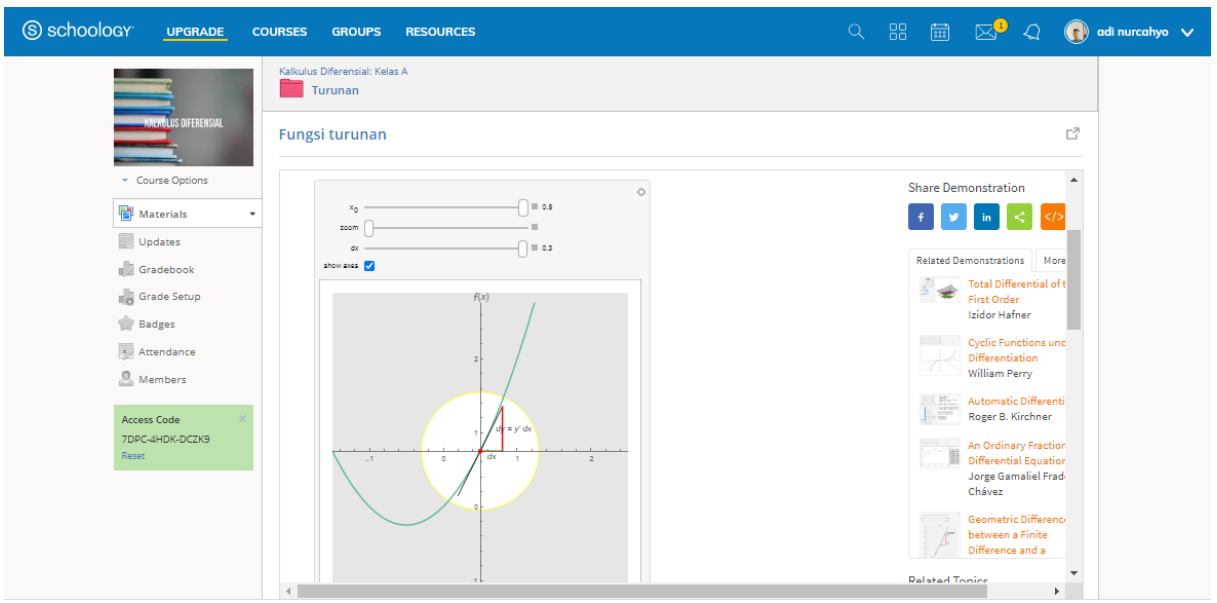

Gambar 2. Tampilan Schoology Kalkulus Diferensial.

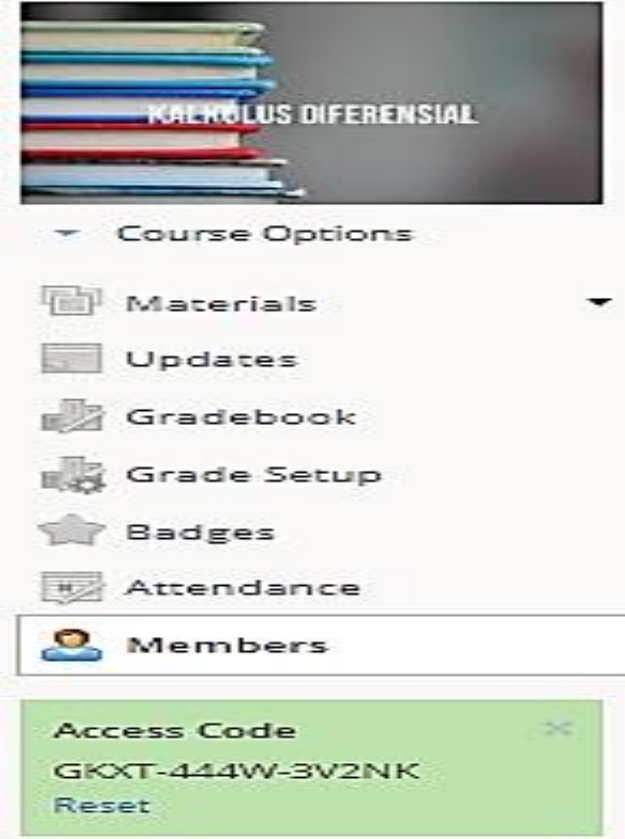

Gambar 3. Kode akses kelas Schoology.

Setelah memasukkan kode akses Schoology dalam kelas kalkulus diferensial, mahasiswa dapat bergabung dalam kelas dan menggunakan fasilitas yang ada dalam kelas semu tersebut. Tampilan daftar mahasiswa yang mengambil mata kuliah kalkulus diferensial pada tahun pelajaran 2019/2021 disajikan pada Gambar 4.

Pada pembahasan topik turunan menunjukkan penjelasan masalah turunan yang ditunjukkan dengan grafik Wolfram CDF player. Dengan adanya tampilan dalam Wolfram, memudahkan mahasiswa untuk memahami permasalahan dalam topik turunan dalam kalkulus diferensial. Topik turunan dengan Wolfram CDF player ditampilkan pada Gambar 5.

Mahasiswa dapat berlatih secara mandiri dan memahami media $e$ learning. Materi turunan menjadi menarik karena dapat digunakan untuk sarana latihan mahasiswa dalam mengetahui penyelesaian persoalan dalam materi kalkulus. Hal ini tentunya dapat meningkatkan motivasi mahasiswa dalam belajar turunan.

Rancangan media e-learning dilakukan validasi oleh ahli materi dan media. Pada penelitian ini terdapat tiga orang ahli media dan tiga orang ahli materi. Sebanyak tiga orang ahli materi memberikan penilaian bahwa materi yang dibuat memiliki kategori yang sangat baik. Sedangkan pada media yang dibuat sebanyak 2 orang ahli menyatakan media sangat baik dan 1 orang ahli media menyatakan media baik. Oleh karena itu, media pembelajaran e-learning berbasis kelas semu Schoology layak diuji coba. Hasil validasi media dapat dilihat pada Gambar 5 tentang penilaian ahli media dan hasil validasi materi pada Gambar 6 tentang penilaian ahli materi. 
DOI: https://doi.org/10.24127/ajpm.v9i4.3137

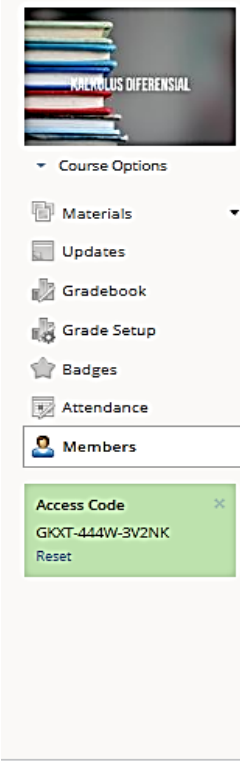

FKIP-P.MAT Kalkulus Diferensial: Kelas 20 ...

Members

All Members Admins
Angelia rizki purwanti A410170002

Gambar 4. Tampilan peserta kelas Kalkulus Diferensial.

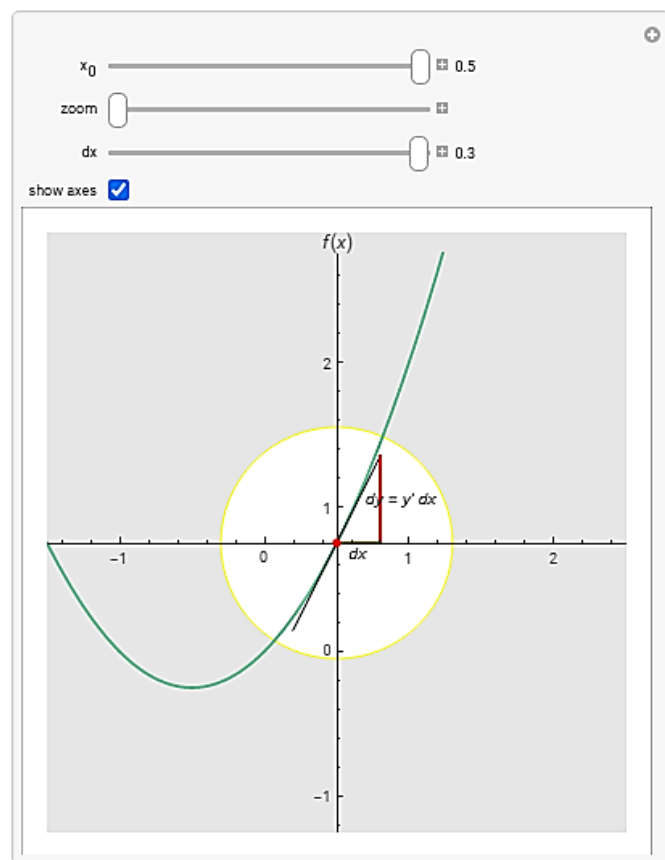

Gambar 5. Gambar bahasan topik turunan dalam kelas semu Schoology.

Berdasarkan hasil yang didapat dari penilaian ahli media bahwa secara keseluruhan validator menyatakan media pembelajaran kelas semu yang digunakan sangat baik. Pembelajaran interaktif kalkulus online dengan kelas

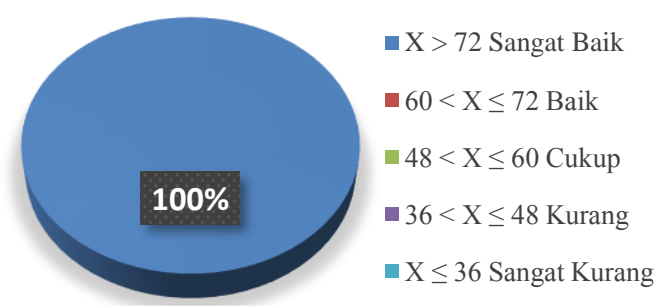

Gambar 5. Penilaian ahli media.

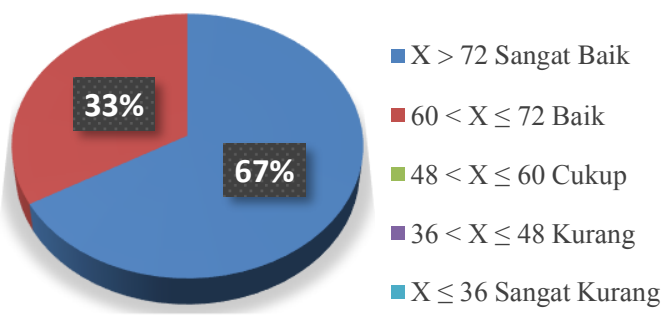

Gambar 6. Penilaian ahli materi.

semu dapat meningkatkan minat mahasiswa terhadap pembelajaran kalkulus. Dengan adanya kelas semu, mahasiswa lebih tertarik untuk mempelajari kalkulus karena tampilan kelas yang digunakan memudahkan 
mahasiswa untuk memahami belajar secara mandiri, belajar berkelompok, maupun berinteraksi dengan pengajar. Pembelajaran kelas online memberikan efek yang positif terhadap kompetensi mahasiswa (Lim \& Morris, 2009). Kompetensi dalam pembelajaran kalkulus tentunya akan meningkat dengan adanya pembelajaran kalkulus online dengan kelas semu Schoology. Materi yang dibuat dalam kelas semu pembelajaran kalkulus dapat digunakan dalam pembelajaran dan dinyatakan baik oleh validator materi. Dalam pembelajaran kelas semu kalkulus dengan aplikasi Wolfram CDF player dapat menunjang aktivitas pembelajaran yang dilakukan. Penggunaan Wolfram CDF dengan penerapan pada kalkulus diferensial membantu mahasiswa untuk

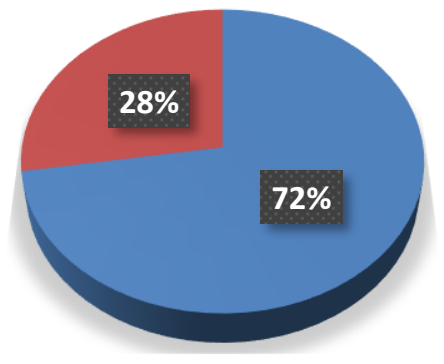

$$
\begin{aligned}
& \square>72 \text { Sangat Baik } \\
& \square 0<X \leq 72 \text { Baik } \\
& -48<X \leq 60 \text { Cukup } \\
& \square 36<X \leq 48 \text { Kurang } \\
& -X \leq 36 \text { Sangat Kurang }
\end{aligned}
$$

mengimplementasikan materi kalkulus secara langsung. Aplikasi penerapan materi membantu pemahaman konsep mahasiswa dan membantu mahasiswa mempelajari materi perkuliahan (Suana et al., 2017). Dengan adanya penerapan materi yang diberikan, mahasiswa lebih mudah memahami materi dalam pembelajaran kalkulus.

Pada penelitian ini dilakukam pengukuran yang meliputi materi dan media. Bagian materi terdapat 17 item pernyataan yang meliputi kelayakan, pemahaman, sistematika, kelengkapan. Sedangkan pada bagian media terdapat 22 item pernyataan yang meliputi desain pembelajaran dan desain tampilan. Hasil pengukuran terhadap 120 mahasiswa disajikan Gambar 7.

Gambar 7. Hasil pengukuran terhadap mahasiswa.

Berdasarkan hasil pada Gambar 7 tentang pengukuran dari 120 mahasiswa didapat sebanyak 87 mahasiswa menyatakan bahwa media pembelajaran tergolong sangat baik. Sedangkan 33 mahasiswa menyatakan media pembelajaran tergolong baik.

Sejalan dengan hasil positif yang diperoleh dari validator terhadap validasi media dan materi, mahasiswa juga memberikan respon positif terhadap media pembelajaran yang digunakan. Sebanyak 73\% mahasiswa menyatakan media pembelajaran yang digunakan sangat baik. Dengan adanya pembelajaran kelas semu yang digunakan, mahasiswa juga mendapatkan beberapa manfaat lain dalam pembelajaran kelas online. Manfaat yang diperoleh diantaranya pemahaman tentang kemampuan informasi dan teknologi. Menurut (Rahmat, 2015) penerapan media pembelajaran interaktif dalam pembelajaran penting untuk digunakan. Adanya pembelajaran online menumbuhkan kemauan belajar secara mandiri (Parkes et al., 2011), partisipasi aktif siswa (Pratama \& Nur Ismiyati, 2019) dan meningkatkan kemampuan ICT (O’dwyer et al., 2007). 
DOI: https://doi.org/10.24127/ajpm.v9i4.3137

Pembelajaran interaktif kalkulus dengan kelas semu Schoology dapat digunakan dalam pembelajaran Kalkulus Diferensial. Hal tersebut sejalan dengan penelitian yang mengungkapkan Schoology sangat baik untuk digunakan dalam pembelajaran online (Mashuri \& Nasrum, 2020; Sari et al., 2020). Dengan adanya Schoology, mahasiswa lebih tertarik dalam pembelajaran yang dilakukan, dikarenakan mahasiswa dapat saling berinteraksi dengan teman dan bertanya langsung kepada dosen dalam forum diskusi. Dengan pembelajaran menggunakan Schoology, mahasiswa mengungkapkan ketertarikannya dalam pembelajaran karena bisa belajar secara daring dan mencari informasi di internet (Sari, Fitriasari, \& Octaria, 2020). Schoology merupakan LMS yang revolusioner dengan tampilan seperti media sosial yang memudahkan pengguna untuk membuat dan menampilkan tugas akademik (Ferdianto \& Dwiniasih, 2019). Kemudahan yang ada dalam LMS Schoology akan membantu dosen untuk mempersiapkan perangkat yang dibutuhkan dalam pembelajaran. Forum diskusi, hand out perkuliahan, tugas, dan penilaian merupakan perangkat yang dibutuhkan dalam pembelajaran online. Schoology memudahkan dosen dalam mempersiapkan pembelajaran online dengan adanya sarana untuk upload handout, diskusi online, dan pertanyaan tes online (Suana et al., 2017).

Schoology dapat memudahkan dosen dalam menyampaikan materi dan mahasiswa dalam memahami materi kalkulus (Ferdianto \& Dwiniasih, 2019; Wardono \& Mariani, 2020). Melalui LMS Schoology, mahasiswa dan pengajar dapat saling berinteraksi secara digital dalam pembelajaran
(Murtikusuma et al., 2019). Diharapkan LMS Schoology dapat menjadi media yang memudahkan mahasiswa untuk berpartisipasi aktif dalam pembelajaran. Sehingga pada akhirnya mahasiswa memahami materi kalkulus yang diberikan.

Hasil dari penelitian ini berupa suatu media pembelajaran interaktif kalkulus dengan kelas semu Schoology. Dengan adanya media tersebut dapat digunakan sebagai alternatif solusi dalam pembelajaran kalkulus. Penerapan teknologi yang dilakukan dengan Wolfram CDF dan Schoology membantu dalam kegiatan pembelajaran.

\section{KESIMPULAN DAN SARAN}

Hasil dari penelitian ini berupa suatu media pembelajaran interaktif kalkulus dengan kelas semu Schoology. Penerapan teknologi yang dilakukan dengan Wolfram CDF dan Schoology membantu dalam kegiatan pembelajaran. Sebanyak 87 mahasiswa menyatakan media pembelajaran tergolong sangat baik dan 33 mahasiswa menyatakan media pembelajaran tergolong baik. Penelitian selanjutnya dapat menggunakan Wolfram $\mathrm{CDF}$ player untuk pembelajaran dalam materi antiderivatif.

\section{DAFTAR PUSTAKA}

Afriyanti, I., Wardono, W., \& Kartono, K. (2018). Pengembangan Literasi Matematika Mengacu PISA Melalui Pembelajaran Abad Ke-21 Berbasis Teknologi. PRISMA, Prosiding Seminar Nasional Matematika, 608-617. https://journal.unnes.ac.id/sju/inde x.php/prisma/article/view/20202

Aldiab, A., Chowdhury, H., Kootsookos, A., Alam, F., \& Allhibi, H. (2019). Utilization of 
DOI: https://doi.org/10.24127/ajpm.v9i4.3137

Learning Management Systems (LMSs) in higher education system: A case review for Saudi Arabia. Energy Procedia, 160(2018), 731-737. https://doi.org/10.1016/j.egypro.20 19.02.186

Ardianti, S., Sulisworo, D., \& Pramudya, Y. (2019). Efektivitas Blended Learning Berbasis Pendekatan Stem Education Berbantuan Schoology Untuk Meningkatkan Critical Thinking Skill Pada Materi Fluida Dinamik. Prosiding Seminar Nasional Pendidikan KALUNI, 240-246. https://doi.org/10.30998/prokaluni. v2i0.67

Areerachakul, S. (2015). Using Electronic Medias for Science Mathematic and English in School under Office of the Basic Education Commission, Thailand. Procedia - Social and Behavioral Sciences, 197(February), 15581563.

https://doi.org/10.1016/j.sbspro.20 15.07.110

Attard, C., \& Holmes, K. (2020). "It gives you that sense of hope": An exploration of technology use to mediate student engagement with mathematics. Heliyon, 6(1), e02945.

https://doi.org/10.1016/j.heliyon.20 19.e02945

Brahim, N., Mohamed, B., Abdelwahed, N., Ahmed, L., Radouane, K., Khalid, S., \& Mohammed, T. (2014). The Use of the Internet in Moroccan High Schools Mathematics Teaching: State and Perspectives. Procedia Social and Behavioral Sciences, 116, 5175-5179. https://doi.org/10.1016/j.sbspro.20 14.01.1095
Ferdianto, F., \& Dwiniasih. (2019). Learning Management System (LMS) schoology: Why it's important and what it looks like. Journal of Physics: Conference Series, $1360(1)$. https://doi.org/10.1088/17426596/1360/1/012034

Firmansyah, B. H. (2015). Pengembangan Blended Learning berbasis Schoology. Teknologi Pembelajaran, 109(1), 5-10. https://doi.org/10.1017/CBO97811 07415324.004

Ghimire, S., Flury, M., Scheenstra, E. J., \& Miles, C. A. (2019). Jo ur na 1 $\mathrm{P}$ re of. Science of the Total Environment, 135577. https://doi.org/10.1016/j.scitotenv. 2019.135577

Gunawan. (2017). Pengembangan Perangkat Pembelajaran Matematika Berbasis Konstruktivisme. PYTHAGORAS: Jurnal Pendidikan Matematika, 12(1), 47-56. https://doi.org/10.21831/pg.v12i1.1 4054

Hidayat, W., \& Sudibyo, N. A. (2018). Implementasi Pembelajaran Interaktif Elektronika Dasar Menggunakan Adobe Flash CS6 Pada Kelas Semu dengan Google Classroom Berbasis Framework RAD. Sains Dan Edukasi Sains, 1(2), 17-24.

Khouyibaba, S. (2010). Teaching mathematics with technology. Procedia - Social and Behavioral Sciences, 9, 638-643. https://doi.org/10.1016/j.sbspro.20 10.12.210 
Lim, D. H., \& Morris, M. L. (2009). International Forum of Educational Technology \& Society Learner and Instructional Factors Influencing Learning Outcomes within a Blended Learning Environment. Source: Journal of Educational Technology \& Society, 12(4), 282293.

https://doi.org/10.2307/jeductechso ci.12.4.282

Mashuri, S., \& Nasrum, A. (2020). Efek Pembelajaran Tambahan Menggunakan Schoology pada Mata Kuliah Kalkulus. AKSIOMA: Jurnal Program Studi Pendidikan Matematika, 9(3), 561-569. https://doi.org/10.24127/ajpm.v9i3. 2790

Monariska, E. (2019). Analisis kesulitan belajar mahasiswa Pada materi integral. Jurnal Analisa, 5(1), 919.

https://doi.org/10.15575/ja.v5i1.41 81

Murtikusuma, R. P., Fatahillah, A., Oktavianingtyas, E., Hussen, S., \& Lailiya, N. (2019). The development of interactive mathematics learning media based on schoology and visual basic through industrial revolution 4.0. IOP Conference Series: Earth and Environmental Science, 243(1), 06. https://doi.org/10.1088/17551315/243/1/012137

O'dwyer, L. M., Carey, R., \& Kleiman, G. (2007). A study of the effectiveness of the louisiana algebra i online course. Journal of Research on Technology in Education, 39(3), 289-306. https://doi.org/10.1080/15391523.2 007.10782484

Parkes, S., Zaka, P., \& Davis, N. (2011). The first blended or hybrid online course in a New Zealand secondary school: A case study. Computers in New Zealand Schools: Learning Teaching, Technology, 23(1), 1-30.

Pratama, R. A., \& Nur Ismiyati. (2019). Pembelajaran Matematika Berbasis Edmodo pada Mata Kuliah Teori Bilangan. AKSIOMA: Jurnal Program Studi Pendidikan Matematika, 8(2), 298-309. https://doi.org/10.24127/ajpm.v8i2. 2125

Rahmat, S. T. (2015). Pemanfaatan Multimedia Interaktif Berbasis Komputer Dalam Pembelajaran. Jurnal Pendiikan Dan Kebudayaan Missio, 7(2), 196-208.

Rejeki, S., \& Setyaningsih, R. (2016). Kontribusi Kemampuan Kalkulus Differensial Dan Kalkulus Integral Terhadap Hasil Belajar Mata Kuliah Persamaan Differensial. JIPMat, l(1). https://doi.org/10.26877/jipmat.v1i 1.1084

Rifa'i, M. (2019). Penerapan Media Pembelajaran Kalkulus Berbasis Website Moodle untuk Menilai Aktivitas dan Hasil Belajar Mahasiswa STKIP Qomaruddin Gresik. Zeta - Math Journal, 4(2), 50-54.

https://doi.org/10.31102/zeta.2019. 4.2.50-54

Rosalina, M. (2018). Analysis The Use of Schoology E-Learning Towards Students' Learning Motivation Enhancement in STKIP Surya. Indonesian Journal of Science and Education, $2(1), \quad 89$. https://doi.org/10.31002/ijose.v2i1. 614

Saputra, N. N., \& Andriyani, R. (2019). Pengembangan perangkat pembelajaran matematika interaktif kelas VIII SMP berbasis konstruktivis. Prima: Jurnal Pendidikan Matematika, 6(1), 1-12. 
Sari, N., Fitriasari, P., \& Octaria, D. (2020). Blended learning with schoology in learning macromedia flash-based instructional media. Journal of Physics: Conference Series, $\quad 1480(1), \quad 0-7$. https://doi.org/10.1088/17426596/1480/1/012053

Slamet HW. (2007). Kalkulus II. Muhammadiyah University Press.

Srisawasdi, N., \& Panjaburee, P. (2014). Technology-enhanced Learning in Science, Technology, and Mathematics Education: Results on Supporting Student Learning. Procedia - Social and Behavioral Sciences, 116, 946950.

https://doi.org/10.1016/j.sbspro.20 14.01.325

Suana, W., Maharta, N., Nyeneng, I. D. P., \& Wahyuni, S. (2017). Design and Implementation od SchoologyBased Blended Learning Media for Basic Physics I Course. Jurnal Pendidikan IPA Indonesia, 6(1), 170-178.

https://doi.org/10.15294/jpii.v6i1.7 205

Suprihatiningsih, S., Sudibyo, N. A., \& Harmini, T. (2020). Eksperimentasi Mobile Learning Pada Mata Kuliah Kalkulus Integral Ditinjau Dari Kemampuan Bekerjasama. Buana Matematika: Jurnal Ilmiah Matematika Dan Pendidikan Matematika, 10(1), 17-30.

https://doi.org/10.36456/buanamat ematika.v10i1.2488
Susandi, A., \& Widyawati, S. (2017). Proses Berpikir dalam Memecahkan Masalah Logika Matematika Ditinjau dari Gaya Kognitif Field Independent dan Field Dependent. NUMERICAL: Jurnal Matematika Dan Pendidikan Matematika, 1(1), 4552.

https://doi.org/10.25217/numerical. v1i1.122

Wahyudi, I. (2017). Pengembangan Program Pembelajaran Fisika SMA Berbasis E-Learning dengan Schoology. Jurnal Ilmiah Pendidikan Fisika Al-Biruni, 6(2), 187.

https://doi.org/10.24042/jipfalbirun i.v6i2.1850

Wardono, \& Mariani, S. (2020). Increased mathematical literacy and HOTs through realistic learning assisted by e-schoology. Journal of Physics: Conference Series, 1567(3). https://doi.org/10.1088/17426596/1567/3/032016

Warsito, M. ., \& Djuniadi. (2016). Pengembangan E-Learning berbasis Schoology pada Mata Pelajaran Matematika Kelas VII. Jurnal Pendidikan Matematika FKIP Unissula, 4(1), 91-99. 